\title{
THE IMPACT OF METHODS OF CARE ON THE CONTENT AND COLLECTION OF ZINC AND COPPER WITH THE YIELD OF POTATO TUBERS
}

\author{
Marek Gugała', Krystyna Zarzecka', Anna Sikorska', \\ Honorata Dołęga', Krzysztof Kapela', Ewa Krasnodębska' \\ ' Department Agrotechnology, University of Natural Sciences and Humanities in Siedlce, Prusa 14 Str., 08-110 \\ Siedlce, Poland, e-mail: gugala@uph.edu.pl
}

Received: 2016.04.01 Accepted: 2016.08.07 Published: 2016.09.20

\begin{abstract}
The study results were obtained from a field experiment conducted in 2012-2014 in Wojnów. The two factor experiment was set up in the split-plot system in triplicate. The investigated factors were: I - three varieties of edible potato: Bartek, Gawin and Honorata. II - five ways of care: 1. Harrier herbicide 295 ZC -2.0 $\mathrm{dm}^{3} \cdot \mathrm{ha}^{-1} ; 2$. Harrier herbicide $295 \mathrm{ZC}-2.0 \mathrm{dm}^{3} \cdot \mathrm{ha}^{-1}$ with the biostimulator Kelpak $\mathrm{SL}-4.0 \mathrm{dm}^{3} \cdot \mathrm{ha}^{-1} ; 3$. Sencor herbicide $70 \mathrm{WG}-1.0 \mathrm{~kg} \cdot \mathrm{ha}^{-1} ; 4$. Sencor herbicide 70 $\mathrm{WG}-1.0 \mathrm{~kg} \cdot \mathrm{ha}^{-1}$ with the biostimulator Asahi SL $-1.5 \mathrm{dm}^{3} \cdot \mathrm{ha}^{-1} ; 5$. The control object - mechanical care. The content of zinc and copper and their collection with the yield of tubers significantly depended on the ways of care, genetic factor and climatic conditions in the years of the study. In the objects $(2,4)$ where herbicides were used with biostimulators, a greater concentration of zinc was obtained in relation to the control object and the remaining $(3,5)$ in which only herbicides were used. The applied care methods did not affect the content of copper in the analysed tubers. The greatest collection of zinc an copper with the yield of tubers was obtained in the objects: where the mixture of the Sencor herbicide $70 \mathrm{WG}-$ $1.0 \mathrm{~kg} \cdot \mathrm{ha}^{-1}$ was used with the biostimulator Asahi SL $-1.5 \mathrm{dm}^{3} \mathrm{ha}^{-1}$ and herbicide Sencor $70 \mathrm{WG}$ in a dose of $-1.0 \mathrm{~kg} \cdot \mathrm{ha}^{-1}$.
\end{abstract}

Keywords: variety, herbicides, biostimulators, zinc, copper, potato

\section{INTRODUCTION}

Potato is one of the most important crops used in human nutrition. Potato tubers are a valuable source of many nutrients, such as: starch, sugars, protein, vitamins $(\mathrm{C}, \mathrm{PP}$, from the $\mathrm{B}$ group), minerals ( $\mathrm{K}, \mathrm{Mg}, \mathrm{Fe}, \mathrm{Cu}, \mathrm{J}, \mathrm{Zn})$ and fibre [Gopalani et al. 2007, Camire et al. 2009, Brown et al. 2011]. According to Rudzińska-Mękal and Mikos-Bielak [2000] the consumption of 200 $\mathrm{g}$ covers up to $12 \%$ of the daily requirements for zinc and copper. Kita and Lisińska [2007], Zarzecka [2009], Brown [2014] believe that the high nutritional value of potatoes results from the low contents of anti-nutritional substances, such as: glycoalkaloids, nitrates, heavy metals, pesticide residues.
The content of minerals in tubers is determined by the genetic features of the variety. Many authors [Klikocka 2001, Gugała et al. 2009, Szewczuk 2009] showed that the chemical composition may change under the influence of the climatic conditions and agronomic factors, including herbicides. According to Budzyński et al. [1996] some pesticides can cause the favourable or unfavourable changes in the chemical composition and the technological properties of the yield of crops. Zarzecka et al. [2011] stated that the use of herbicides impacts the size of the yield, but it can also degrade the quality characteristics and the consumption value of tubers. Sawicka and Pszczółkowski [2005] demonstrated that pesticides applied in appropriate doses and times do not cause significant changes in the chemical composition of tubers. 
The aim of the study was to determine the impact of the use of selected ways of care on the content and collection of zinc and copper with the yield of tubers of three edible potato varieties.

\section{MATERIAL AND METHODS}

The study results were obtained from a field experiment conducted in 2012-2014 in Wojnów. The two factor experiment was set up in the split-plot system in triplicate. The investigated factors were: I - three varieties of edible potato: Bartek, Gawin and Honorata. II - five ways of care: 1 . Harrier herbicide $295 \mathrm{ZC}-2.0 \mathrm{dm}^{3} \cdot \mathrm{ha}^{-1}$, 2. Harrier herbicide $295 \mathrm{ZC}-2.0 \mathrm{dm}^{3} \cdot \mathrm{ha}^{-1}$ with the biostimulator Kelpak SL $-4.0 \mathrm{dm}^{3} \cdot \mathrm{ha}^{-1} ; 3$. Sencor herbicide $70 \mathrm{WG}-1.0 \mathrm{~kg} \cdot \mathrm{ha}^{-1}$; 4 . Sencor herbicide $70 \mathrm{WG}-1.0 \mathrm{~kg} \cdot \mathrm{ha}^{-1}$ with the biostimulator Asahi SL $-1.5 \mathrm{dm}^{3} \cdot \mathrm{ha}^{-1} ; 5$. The control object - without the chemical protection.

Potatoes were grown in the position of the winter wheat. In the experiment the permanent organic fertilisation was used with the manure in the amount of $25.0 \mathrm{t} \cdot \mathrm{ha}^{-1}$ and mineral in the amounts of: $100 \mathrm{~kg} \cdot \mathrm{ha}^{-1} \mathrm{P}_{2} \mathrm{O}_{5}, 150 \mathrm{~kg} \cdot \mathrm{ha}^{-1} \mathrm{~K}_{2} \mathrm{O}$, $100 \mathrm{~kg} \cdot \mathrm{ha}^{-1} \mathrm{~N}$. The collection was carried out in the stage of technological maturity of tubers.
The content of zinc and copper in potato tubers was determined with the method of atomic absorption spectrophotometry (ASA). The test results were developed statistically by the analysis of variance. The significance of the sources of variation was tested with the "F" Fischer-Snedecor test, and the assessment of the difference significance at the level of significance $\mathrm{p}=0.05$ between the compared averages, using the multiple Tukey ranges.

The characteristics of the climatic conditions were presented using the hydrothermal Sielianinow coefficient, monthly precipitation an average air temperatures for each year of the study (Table 1). The growing season 2012 was characterised by a weak drought. While in the remaining years of the study there was no drought (mean coefficient value $\geq 1$ ). The lowest average amount of precipitation (264.9 $\mathrm{mm}$ ) was noted in 2012. It was the year with the highest average air temperature $\left(15.4^{\circ} \mathrm{C}\right)$. The year of 2013 was distinguished by excessive rainfall $(441.3 \mathrm{~mm})$ in relation to the average sum of many years and it was the coolest compared to other growing seasons. The growing year of 2014 was also characterised by the high average rainfall $(335.1 \mathrm{~mm})$ in relation to the multi-year period at an average air temperature of $15.3^{\circ} \mathrm{C}$.

Table 1. Weather conditions in potato growing season in years 2012-2014 (Zawady Meteorological Station)

\begin{tabular}{|c|c|c|c|c|c|c|c|}
\hline \multirow{2}{*}{ Years } & \multicolumn{7}{|c|}{ Months } \\
\hline & IV & $\mathrm{V}$ & VI & VII & VIII & IX & IV-IX \\
\hline \multicolumn{7}{|c|}{ Rainfalls (mm) } & Sum \\
\hline 2012 & 29.9 & 53.4 & 76.2 & 43.0 & 51.0 & 11.4 & 264.9 \\
\hline 2013 & 36.0 & 105.9 & 98.8 & 91.3 & 15.0 & 94.3 & 441.3 \\
\hline 2014 & 45.0 & 92.7 & 55.4 & 10.0 & 105.7 & 26.3 & 335.1 \\
\hline Multiyear sum (1987-2000) & 38.6 & 44.1 & 52.4 & 49.8 & 43.0 & 47.3 & 275.2 \\
\hline \multicolumn{7}{|c|}{ Air temperature $\left({ }^{\circ} \mathrm{C}\right)$} & Mean \\
\hline 2012 & 8.9 & 14.6 & 16.3 & 20.7 & 18.0 & 14.1 & 15.4 \\
\hline 2013 & 7.4 & 15.3 & 18.0 & 19.0 & 18.8 & 11.7 & 15.0 \\
\hline 2014 & 9.8 & 13.5 & 15.4 & 20.8 & 18.1 & 14.1 & 15.3 \\
\hline Multiyear mean (1987-2000) & 7.8 & 12.5 & 17.2 & 19.2 & 18.5 & 13.1 & 14.7 \\
\hline \multicolumn{7}{|c|}{ Sielianinovs hydrothermic coefficients } & Mean \\
\hline 2012 & 1.10 & 1.20 & 1.60 & 0.69 & 0.94 & 0.27 & 0.95 \\
\hline 2013 & 1.60 & 2.30 & 1.80 & 1.60 & 0.30 & 2.70 & 1.60 \\
\hline 2014 & 1.50 & 2.30 & 1.20 & 0.16 & 1.90 & 0.62 & 1.20 \\
\hline
\end{tabular}

Value of coefficients Sielianinovs:

$<0.5$ - strong mild drought;

0.51-0.69 - mild;

0.70-0.99 - weak mild drought;

$\geq 1$ - fault drought 


\section{RESULTS AND DISCUSSIONS}

The conducted studies showed that the genetic factor had a significant impact on the content of zinc in the potato tubers (Table 2). The highest mean content of the element was obtained in the Bartek variety $\left(21.28 \mathrm{mg} \cdot \mathrm{kg}^{-1} \mathrm{~s} . \mathrm{m}\right.$.). This variety was characterised by the lowest average element collection $\left(187.0 \mathrm{~g} \cdot \mathrm{ha}^{-1}\right)$. The lowest average zinc content was obtained in the Honorata variety $\left(20.72 \mathrm{mg} \cdot \mathrm{kg}^{-1} \mathrm{~s}\right.$.m. $)$. The variety was characterised by the greatest average collection of the element $\left(219.1 \mathrm{~g} \cdot \mathrm{ha}^{-1}\right)$ from the yield of tubers (Table 3 ). Similar conclusions were reached by other authors [Zarzecka 2003, Wierzbowska et al. 2015], who showed the significant difference between the varieties in the zinc content in the potato tubers. The care methods used in the experiment had a significant impact on the content and collection of zinc with the yield of tubers compared to the control object. The greatest content and ability to collect the element was noted in objects, where herbicides were used with biostimulators (Table 2, 3). After the application with the Sencor herbicide $70 \mathrm{WG}-1.0 \mathrm{~kg} \mathrm{ha}^{-1}$ with the biostimulator Asahi SL $-1.5 \mathrm{dm}^{3} \cdot \mathrm{ha}^{-1}$ the average zinc content was $21.31 \mathrm{mg} \cdot \mathrm{kg}^{-1} \mathrm{~s} . \mathrm{m}$. of tubers, and the collection with the yield of tubers $-231.7 \mathrm{~g} \cdot \mathrm{ha}^{-1} \mathrm{Zn}$. A similar average of the element (21.07 $\mathrm{mg} \cdot \mathrm{kg}^{-1} \mathrm{Zn} \mathrm{w} \mathrm{s.m)} \mathrm{was} \mathrm{noted} \mathrm{in} \mathrm{the}$ object 2, after the application of the Harrier herbicide $295 \mathrm{Z} \mathrm{C}-2.0 \mathrm{dm}^{3} \mathrm{ha}^{-1}$ with the biostimulator Kelpak SL $-4.0 \mathrm{dm}^{3} \cdot \mathrm{ha}^{-1}$. The high collection of the element $\left(218.3 \mathrm{~g} \cdot \mathrm{ha}^{-1}\right)$ was obtained in the object 4 (Sencor $70 \mathrm{WG}$ in the dose of $1.0 \mathrm{~kg} \mathrm{ha}^{-}$ $\left.{ }^{1}\right)$. Similar results were obtained by RudzińskaMękal and Mikos-Bielak [2000].

Also in the studies by Wierzbowska et al. [2015] the potato tubers treated with the biostimulator Kelpak were characterised with the highest zinc content. In turn, according to Zarzecka [2003] and Zarzecka and Gugała [2009] the use of herbicides affected the reduction of the zinc content in the analysed tubers. A significant impact of weather conditions on the content and collection of microelements with the yield of tubers was

Table 2. Content of zinc in potato tubers $\left(\mathrm{mg} \cdot \mathrm{kg}^{-1}\right.$ dry matter)

\begin{tabular}{|c|c|c|c|c|c|c|c|}
\hline \multirow{2}{*}{ Weed control methods } & \multicolumn{3}{|c|}{ Years } & \multicolumn{3}{|c|}{ Cultivars } & \multirow{2}{*}{ Mean } \\
\hline & 2012 & 2013 & 2014 & Bartek & Gawin & Honorata & \\
\hline 1. Control object & 20.81 & 20.40 & 20.67 & 20.89 & 20.52 & 20.47 & 20.63 \\
\hline 2. Harrier $295 \mathrm{ZC} 2.0 \mathrm{dm}^{3} \cdot \mathrm{ha}^{-1}$ & 20.87 & 20.72 & 20.90 & 21.21 & 20.68 & 20.60 & 20.83 \\
\hline $\begin{array}{l}\text { 3. Harrier } 295 \text { ZC } 2.0 \mathrm{dm}^{3} \cdot \mathrm{ha}^{-1}+ \\
\text { Kelpak SL } 4.0 \mathrm{dm}^{3} \cdot \mathrm{ha}^{-1}\end{array}$ & 21.33 & 20.86 & 21.01 & 21.42 & 20.87 & 20.91 & 21.07 \\
\hline 4. Sencor 70 WG $1.0 \mathrm{~kg} \cdot \mathrm{ha}^{-1}$ & 20.91 & 20.91 & 20.92 & 21.29 & 20.93 & 20.52 & 20.91 \\
\hline $\begin{array}{l}\text { 5. Sencor } 70 \text { WG } 1.0 \mathrm{~kg} \cdot \mathrm{ha}^{-1}+\text { Asahi } \\
\mathrm{SL} 1.5 \mathrm{dm}^{3} \cdot \mathrm{ha}^{-1}\end{array}$ & 21.38 & 21.45 & 21.11 & 21.60 & 21.22 & 21.12 & 21.31 \\
\hline Mean & 21.06 & 20.87 & 20.92 & 21.28 & 20.84 & 20.72 & - \\
\hline $\begin{array}{l}\text { LSD }_{0.05} \text { for: } \\
\text { - yeaars } \\
\text { - cultivars } \\
\text { - weed control methods }\end{array}$ & & & & & & & $\begin{array}{l}0.12 \\
0.12 \\
0.26\end{array}$ \\
\hline
\end{tabular}

Table 3. Uptake of zinc with the yield of potato tubers $\left(\mathrm{g} \cdot \mathrm{ha}^{-1}\right)$

\begin{tabular}{|c|c|c|c|c|c|c|c|}
\hline \multirow{2}{*}{ Weed control methods } & \multicolumn{3}{|c|}{ Years } & \multicolumn{3}{|c|}{ Cultivars } & \multirow{2}{*}{ Mean } \\
\hline & 2012 & 2013 & 2014 & Bartek & Gawin & Honorata & \\
\hline 1. Control object & 208.5 & 147.6 & 139.9 & 154.7 & 165.7 & 175.6 & 165.3 \\
\hline 2. Harrier $295 \mathrm{ZC} 2.0 \mathrm{dm}^{3} \cdot \mathrm{ha}^{-1}$ & 232.2 & 180.7 & 156.7 & 172.8 & 187.4 & 209.4 & 189.9 \\
\hline $\begin{array}{l}\text { 3. Harrier } 295 \mathrm{ZC} 2.0 \mathrm{dm}^{3} \cdot \mathrm{ha}^{-1}+ \\
\text { Kelpak SL } 4.0 \mathrm{dm}^{3} \cdot \mathrm{ha}^{-1}\end{array}$ & 276.5 & 182.0 & 166.0 & 194.3 & 207.5 & 222.7 & 208.2 \\
\hline 4. Sencor 70 WG $1.0 \mathrm{~kg} \cdot \mathrm{ha}^{-1}$ & 272.8 & 188.5 & 193.5 & 199.5 & 217.9 & 237.4 & 218.3 \\
\hline $\begin{array}{l}\text { 5. Sencor } 70 \text { WG } 1.0 \mathrm{~kg} \cdot \mathrm{ha}^{-1}+\text { Asahi } \\
\mathrm{SL} 1.5 \mathrm{dm}^{3} \cdot \mathrm{ha}^{-1}\end{array}$ & 287.1 & 204.1 & 203.9 & 213.8 & 230.6 & 250.7 & 231.7 \\
\hline Mean & 255.4 & 180.6 & 172.0 & 187.0 & 201.8 & 219.1 & - \\
\hline $\begin{array}{l}\mathrm{LSD}_{0.05} \text { for: } \\
\text { - years } \\
\text { - cultivars } \\
\text { - weed control methods } \\
\text { Interaction: } \\
\text { - years } \times \text { weed control methods }\end{array}$ & & & & & & & $\begin{array}{l}11.4 \\
11.4 \\
11.1 \\
6.07\end{array}$ \\
\hline
\end{tabular}


presented by Medyńska et al. [2009], Gugała and Zarzecka [2011]. In the analysed growing seasons the significant differentiation of the content and collection of zinc was with the yield of tubers was noted (Table 2, 3). In 2012 the highest average concentration (21.06 mg $\cdot \mathrm{kg}^{-1} \mathrm{~s} . \mathrm{m}$.) and collection of the element $\left(255.4 \mathrm{~g} \cdot \mathrm{ha}^{-1}\right)$ was obtained. It was the year with the lowest total rainfall and the highest average air temperature. In the other seasons with the excessive rainfall the similar value and collection of the element with the yield of tubers was obtained. The average content of copper in potato tubers ranged from 6.038 to $6.532 \mathrm{mg} \cdot \mathrm{ha}^{-1}$ s.m. and depended significantly on the cultivar factor (Table 4).

The highest average of the element content was noted in the Gawin variety, and the smallest one in the Honorata variety, which was characterised by the greatest ability to collect copper $\left(67.99 \mathrm{~g} \cdot \mathrm{ha}^{-1}\right)$ with the yield of tubers. Among the studied varieties, the lowest element collection $\left(51.99 \mathrm{~g} \cdot \mathrm{ha}^{-1}\right)$ was noted in the Bartek variety (Table 5). The differences between the varieties in the copper content were shown by Browszys et al. [2009], Zarzecka and Gugała [2009], Gugała and Zarzecka [2011], Wierzbowska et al. [2015]. The chemical care methods applied in the experiment did not affect the concentrations of copper in potato tubers (Table 4$)$. The objects $(2,3,4,5)$ where the chemical pesticides were used the statistically insignificant differences were noted in relation to the control object.

Different test results were obtained by Wierzbowska et al. [2015]. The authors found the significant increase in the copper concentration in the tubers under the use of the biostimulator Kelpak. In own studies, the greatest average element collection occurred in the object 5 , where the Sencor herbicide $70 \mathrm{WG}-1.0 \mathrm{~kg} \mathrm{ha}^{-1}$ was used with the biostimulator Asahi SL $-1.5 \mathrm{dm}^{3}$ $\mathrm{ha}^{-1}$ and 4 , where only Sencor $70 \mathrm{WG}-1.0 \mathrm{~kg}$ $\mathrm{ha}^{-1}$ was used. These results are consistent with the research conducted by Westermann [2005], Grzyś [2012], from which results that the use of biostimulators affected the increase of the copper collection with the yield of potato tubers. The cli-

Table 4. Content of copper in potato tubers $\left(\mathrm{mg} \cdot \mathrm{kg}^{-1}\right.$ dry matter)

\begin{tabular}{|c|c|c|c|c|c|c|c|}
\hline \multirow{2}{*}{ Weed control methods } & \multicolumn{3}{|c|}{ Years } & \multicolumn{3}{|c|}{ Cultivars } & \multirow{2}{*}{ Mean } \\
\hline & 2012 & 2013 & 2014 & Bartek & Gawin & Honorata & \\
\hline 1. Control object & 5.984 & 6.503 & 6.493 & 6.016 & 6.532 & 6.432 & 6.327 \\
\hline 2. Harrier 295 ZC $2.0 \mathrm{dm}^{3} \cdot \mathrm{ha}^{-1}$ & 5.945 & 6.437 & 6.495 & 5.983 & 6.513 & 6.380 & 6.292 \\
\hline $\begin{array}{l}\text { 3. Harrier } 295 \text { ZC } 2.0 \mathrm{dm}^{3} \cdot \mathrm{ha}^{-1}+ \\
\text { Kelpak SL } 4.0 \mathrm{dm}^{3} \cdot \mathrm{ha}^{-1}\end{array}$ & 6.157 & 6.515 & 6.511 & 6.142 & 6.581 & 6.460 & 6.394 \\
\hline 4. Sencor 70 WG $1.0 \mathrm{~kg} \cdot \mathrm{ha}^{-1}$ & 5.889 & 6.492 & 6.508 & 5.996 & 6.486 & 6.408 & 6.296 \\
\hline $\begin{array}{l}\text { 5. Sencor } 70 \text { WG } 1.0 \mathrm{~kg} \cdot \mathrm{ha}^{-1}+\text { Asahi } \\
\mathrm{SL} 1.5 \mathrm{dm}^{3} \cdot \mathrm{ha}^{-1}\end{array}$ & 6.057 & 6.517 & 6.549 & 6.056 & 6.549 & 6.517 & 6.374 \\
\hline Mean & 6.006 & 6.493 & 6.511 & 6.038 & 6.532 & 6.439 & - \\
\hline $\begin{array}{l}\text { LSD }_{0.05} \text { for: } \\
\text { - years } \\
\text { - cultivars }\end{array}$ & & & & & & & $\begin{array}{l}0.056 \\
0.056\end{array}$ \\
\hline
\end{tabular}

Table 5. Uptake of copper with the yield of potato tubers $\left(\mathrm{g} \cdot \mathrm{ha}^{-1}\right)$

\begin{tabular}{|c|c|c|c|c|c|c|c|}
\hline \multirow{2}{*}{ Sposoby pielęgnacji } & \multicolumn{3}{|c|}{ Years } & \multicolumn{3}{|c|}{ Cultivars } & \multirow{2}{*}{ Mean } \\
\hline & 2012 & 2013 & 2014 & Bartek & Gawin & Honorata & \\
\hline 1. Control object & 59.94 & 47.03 & 44.10 & 43.50 & 52.53 & 55.06 & 50.36 \\
\hline 2. Harrier 295 ZC $2.0 \mathrm{dm}^{3} \cdot \mathrm{ha}^{-1}$ & 66.43 & 56.25 & 48.83 & 47.80 & 58.83 & 64.87 & 57.17 \\
\hline $\begin{array}{l}\text { 3. Harrier } 295 \mathrm{ZC} 2.0 \mathrm{dm}^{3} \cdot \mathrm{ha}^{-1}+ \\
\text { Kelpak SL } 4.0 \mathrm{dm}^{3} \cdot \mathrm{ha}^{-1}\end{array}$ & 79.76 & 56.95 & 51.58 & 54.60 & 65.12 & 68.60 & 62.76 \\
\hline 4. Sencor 70 WG $1.0 \mathrm{~kg} \cdot \mathrm{ha}^{-1}$ & 76.90 & 58.41 & 60.50 & 54.96 & 66.87 & 73.98 & 65.27 \\
\hline $\begin{array}{l}\text { 5. Sencor } 70 \text { WG } 1.0 \mathrm{~kg} \cdot \mathrm{ha}^{-1}+\text { Asahi } \\
\mathrm{SL} 1.5 \mathrm{dm}^{3} \cdot \mathrm{ha}^{-1}\end{array}$ & 81.52 & 62.05 & 63.58 & 58.69 & 70.98 & 77.47 & 69.05 \\
\hline Mean & 72.91 & 56.14 & 53.72 & 51.91 & 62.87 & 67.99 & - \\
\hline $\begin{array}{l}\mathrm{LSD}_{0.05} \text { for: } \\
- \text { years } \\
- \text { cultivars } \\
- \text { weed control methods } \\
\text { Interaction: } \\
\text { - years } \times \text { weed control methods }\end{array}$ & & & & & & & $\begin{array}{l}3.67 \\
3.67 \\
3.50 \\
\\
6.07\end{array}$ \\
\hline
\end{tabular}


matic conditions in the years of the studies had a significant impact on the concentration and collection of copper with the yield of potato tubers (Table 4, 5). The highest content and the lowest collection of the element characterised the tubers collected in 2014, which stood out thanks to its excessive rainfall and high temperature during the growing season. The lowest concentration and the highest collection of copper was obtained in 2012. It was the year with the lowest average total rainfall and the greatest air temperature.

\section{CONCLUSIONS}

1. The herbicides used in the experiment and their mixtures with biostimulators had a significant impact on the increase of the zinc content and collection of zinc and copper with the yield of potato tubers in relation to the control object. The care methods did not impact the concentration of copper in the analysed tubers.

2. The cultivar factor impacted the concentrations and collection of microelements with the yield of tubers. The greatest average content of zinc was shown in the Bartek variety, and copper in the Gawin variety. The Honorata distinguished with the greatest ability to collect microelements with the yield of tubers.

3. The concentration and collection of zinc and copper was impacted by the climatic conditions. The highest content and collection of zinc was noted in the tubers collected in the warm growing season with the average humidity (2012). During this period also the highest collection of copper with the yield of tubers was obtained. The greatest concentration of copper was stated in 2014, which was warm and characterised by excessive rainfall.

\section{REFERENCES}

1. Budzyński W., Szempliński W., Dubis B. 1996. Rolnicza, jakościowa i energetyczna ocena różnych sposobów odchwaszczania i nawożenia azotem jarej pszenicy chlebowej. Rocz. Nauk Rol. Seria A, 112 (1-2),: 81-91.

2. Brown C., Haynes K., Moore M., Pavek M., Hane D., Love S., Novy R., Miller C. 2011. Stability and Broad-sense Heritability of Mineral Content in Potato: Zinc. American Journal of Potato Research, 88 (3), 238-244.
3. Brown C., Haynes K., Moore M., Pavek M., Hane D., Love S., Novy R., Miller, C. 2014. Stability and Broad-Sense Heritability of Mineral Content in Potato: Copper and Sulfur American Journal of Potato Research, 91(6), 618-624.

4. Browszys T., Wierzbowska J., Bowszys J. 2009. Content and removal of $\mathrm{Cu}$ and $\mathrm{Zn}$ with harvested crops grown on soil fertilized with composted municipal sewage sludge. J. Elem., 14(1), 23-32.

5. Camire M., Kubow S., Donnell D. 2009. Potatoes and human health. Critical Reviews in Food Science and Nutrition, 49(10), 823-840.

6. Gopalani M., Shahre M., Ramteke D., Wate S. 2007. Heavy metal content of potato chips and biscuits from Nagpur City, India. Bull Environ Contam Toxicol, 79, 384-387.

7. Grzyś E. 2012. The effect of some biologically active substances on maize grown under stress conditions. Monografie CXLV. Wyd. UP Wrocław 101.

8. Gugała M., Zarzecka K., Mystkowska I. 2009. Wpływ herbicydów na wybrane cechy jakościowe bulw ziemniaka. [The influence of herbicideson selected qualitative traits in potato]. Prog. Plant Prot./ Post. Ochr. Roślin 49 (1), 436-439.

9. Gugała M., Zarzecka K. 2011. Copper and zinc contents in edible potato tubers influenced by an application of new generation insecticides. Fresenius Environmental Bulletin, 20(7a), 1793-1796.

10. Kita A., Lisińska G. 2007. The evaluation of chemical composition and organoleptic quality of frozen potato products from retail. Żywność. Nauka. Technologia. Jakość, 3(52), 15-27.

11. Klikocka H. 2001. Wpływ stosowania różnych sposobów uprawy roli i pielęgnowania ziemniaków na zawartość makroelementów w ich bulwach. Biul. IHAR 217, 197-203.

12. Medyńska A., Kabała C., Chodak T., Jezierski P. 2009. Concentration of copper, zinc lead and cadmium in plants culitivated in the surroundings of Żelazny Most copper ore tailings impoundment.

13. Rudzińska-Mękal B., Mikos-Bielak M. 2000. The influence of growth regulators on the content of microelements in potato tubers. Zeszyty Problemowe Postępów Nauk Rolniczych, 471, 505-512.

14. Sawicka B., Pszczółkowski P. 2005. Dry matter and carbohydrates content in the tubers of very carly potato varieties cultivated under coverage. Acta Sci. Pol., Hortorum Cultus 4 (2), 111-122.

15. Szewczuk C., 2009. Wpływ dokarmiania dolistnego na plon bulw ziemniaka. Annales UMCS, sec. E, Agricultura 64 (1), 7-12.

16. Westermann D. 2005. Nutritional Requirements of Potatoes. Am. J. Potato Res., 82, 301-307

17. Wierzbowska J., Cwalina-Ambroziak B., Bowszys 
T., Głosek-Sobieraj M., Mackiewicz-Walec E. 2015. Content of microelements in tubers of potato treated with biostimulators Pol. Journal Natural Scientist, 30(3), 225-234.

18. Zarzecka K. 2003. Effect of different cultivation methods on copper and zinc contents in potato tubers. J. Elem., 8,1, 41-48.
19. Zarzecka K, Gugała M. 2009. The effect of cultivation operations on the copper and zinc content and accumulation in potato tubers. Fresenius Environmental Bulletin 18(7), 1054-1058.

20. Zarzecka K., Zadrożniak B., Gugała M. 2011. Wpływ insektycydów na cechy konsumpcyjne bulw ziemniaka. Fragm. Agron. 28(3), 129. 